\title{
Politicisation and economic governance design
}

\begin{abstract}
The functional pressures shaping policy design may be disrupted in salient policies and politicised contexts, according to recent postfunctionalist/new intergovernmentalist theories. We contrast these expectations with those derived from liberal intergovernmentalism and neofunctionalism by analysing the reforms of the European Union economic governance. Its Council-centred enforcement, which has been a dominant feature until the euro crisis, despite noncompliance, does not sit comfortably with traditional theories but can be explained by policy salience and implementation uncertainties. Instead, the emphasis that traditional approaches assign to noncompliance, commitment problems, threats of exclusion and veto, issue linkages, path dependencies and supranational decision-making, allows to adequately account for the overall direction of reforms toward more tightening and delegation, notwithstanding the pooled enforcement in recent ancillary measures. Postfunctionalist theories overall fall short in highly politicised contexts, exactly where they should do most of the explaining. We conclude discussing politicization as a strategic elite response.
\end{abstract}

\section{Introduction}

The rules governing economic and fiscal policies in the European Union (EU) are a centrepiece of the economic and monetary union. Over the years, they have become subject to heated public debates. Reforms that originally attracted only the interest of the specialized press generate now broad and polarised public discussions (Kriesi and Grande 2016: 253). How has such politicisation been managed and what are the consequences for the design of these rules? When legislators adopt any EU policy, they take three key design decisions. First, they establish common rules. Second, they determine the modality and extent to which they are involved in policy-making. Third, they determine the 
prerogatives and constraints of the authorities in charge of implementation. In this article, we compare and contrast expectations of policy design derived from liberal intergovernmentalism and neofunctionalism with those arising from a new wave of theorizing, which originates from postfunctionalism and falls under the general rubric of new intergovernmentalism. These new theories argue that politicisation has consequences for policy design that are unaccounted for by traditional approaches. We subject these claims to test by focusing on a policy that is prone to politicisation and by taking advantage of the fact that its most recent reform was significantly more politicised than previous ones.

Studies of economic governance take mainly one theoretical perspective, such as liberal intergovernmentalism (Biermann et al. 2019; Schimmelfennig 2015), neofunctionalism and its variants (Niemann and Ioannou 2015; Verdun 2015) or postfunctionalist-based approaches (e.g. Börzel and Risse 2018; Fabbrini 2016; Genschel and Jachtenfuchs 2018; Puetter 2012). We follow Heipertz and Verdun (2005; 2010) and Schimmelfennig (2014) and consider all the most relevant theories of policy design. Additionally, most works concentrate solely on the most recent reform. We instead analyse economic governance since its inception, building on the extant analyses of the 1997 and 2005 reforms (Heipertz and Verdun 2005; 2010; Schure and Verdun 2008; Segers and van Esch 2007).

But unlike these studies, we subject expectations to empirical corroboration through a systematic analysis of the bargaining dynamics and the provision-specific patterns of governance design adopted between 1993 and 2013. We conceive the design of a policy as characterized by a set of provisions with specific and, occasionally, multiple properties. Tightening provisions impose requirements and obligations on national authorities, whereas loosening ones relax such demands or offer them leeway. For instance, the deficit and debt reference values in the treaty protocol on excessive deficit procedure tightened control over national fiscal policies, while the adoption in 2005 of country-specific (rather than common) medium-term budgetary objectives (MTOs), which can diverge from a balance position, 
loosened control. Pooling provisions are those where the Council takes decisions by voting procedures other than unanimity and delegating ones are those where policy prerogatives are conferred upon the European Commission. Both pooling and delegation can be subject to constraints. For instance, the decision to establish the existence of an excessive deficit is pooled within the Council, but until 2005 exceptional circumstances could be granted only in case of an annual fall of real gross domestic product (GDP) of at least 2 percent. Since 2005, the Commission can amend poor quality data on public finances, subject to prompt communication to the relevant member state and the Economic and Financial Committee.

Do established theories help explain the patterns we observe? Or do they need to be qualified, given the salience and politicisation of the policy? In the conclusion we will engage with the concept of politicization as strategic response but, for the most part the manuscript, politicisation is conceptualized as an expansion of the scope of conflict within national political systems which translates into bottomup pressures on EU-level actors (Bressanelli et al. forthcoming; Schimmelfennig forthcoming). We leverage the documented observation that the recent reform was characterized by significantly more extensive and polarised involvement of public actors - two key politicisation dimensions - than earlier ones (Kriesi and Grande 2016), making such reform a most-likely case for politicisation to shape policy design. How have EU-level actors reacted in response to such pressures? We begin our investigation by introducing the theoretical predictions.

\section{Integration Theories, Politicisation and Policy Design}

We limit our attention to integration theories, or variants therein, that offer clear expectations about policy design. Length constraints prevent us from discussing the full richness of these approaches. These expectations focus on tightening, loosening, pooling and delegation. 
For liberal intergovernmentalism, pooling and delegation are driven by the need to bolster credibility of policy commitments, when incomplete contracting and incentives to renege on agreements create problems of time consistency (Moravcsik 1998: 73-77). Pooling and delegation occur when future decisions are uncertain, joint gains are high and distributional conflicts are moderate. Pooling entails less loss of governmental control than delegation. It is preferred when policies require additional measures because it undermines unilateral vetoes to secondary legislation. In addition to reducing legislative workload, delegation addresses concerns about domestic compliance and it is more likely in enforcement since a supranational bureaucracy pursues this activity more credibly than a Council of elected ministers does. A higher risk of noncompliance should therefore tilt policy design toward delegation (i.e. Commission empowerment) and plausibly tightening.

Opposition is likely to be voiced by governments that expect being either in a minority position or noncompliant. The preferences of governments with superior bargaining power, resulting from asymmetric interdependence, eventually shape outcomes. Most influential are those that a) place relatively higher value to the best alternative to an agreement and that b) can form viable alternative coalitions that are costly to the excluded countries. The first situation underlies credible threats to veto, the second credible threats to exclude. Issue linkages may play a role as well, but within issue areas, if interests are asymmetrically distributed, benefits concentrated and costs diffused (Moravcsik 1998: 60$67)$.

Neofunctionalism encompasses more variegated contributions but a common thread is the emphasis on endogeneity, as well as uncertainty, in policy design (e.g. Heipertz and Verdun 2010: 64-67; Schimmelfennig 2014: 326-327). According to its institutionalist variant, past decisions have profound consequences for current bargaining because of endogenous interdependencies, spillovers and path dependencies (Garrett and Tsebelis 1996; Pierson 1996). Consider an obvious example: a flexible exchange rate is costlier now for Eurozone countries compared to when they were members of the 
European monetary system. The uncertainty and exit cost associated with leaving a monetary union are significant, effectively precluding this option.

Except for the need of centralized expertise which may justify delegation, neofunctionalism does not suggest new logics of policy design (Schimmelfennig 2014: 334). One of its key insights is that a more supranational policy process may lead to different outcomes (i.e. a 'cultivated' spillover effect). The agent/agenda setter's position, institutional hurdles (lower voting thresholds), inter-institutional conflicts may all shape the final design. For instance, demands for tightening and delegation are more likely to be met under qualified majority voting since recalcitrant governments, preferring ample national discretion and narrowly defined Commission's competences, can be overruled. The outcome may tilt further in this direction under the ordinary legislative procedure if the position of European Parliament is closer to that of the supranational executive than to that of the Council (Franchino 2007: 64-5, 285-6).

There is however reason to believe that these traditional rationales may not be at play. According to Genschel and Jachtenfuchs (2018: 181-182), fiscal policy is a core state power where bargaining is zero-sum. Compliance falls predominantly on governmental rather than societal actors; it faces tighter capacity constraints and may require the building up of capacity at the EU level. Negotiations are therefore highly politicised. Moreover, the bargaining context has changed. In a study of six European countries, Kriesi and Grande (2016: 253) report that the latest economic governance reform has been 'the integration debate with the highest public visibility' in the mass media since the early 1970s. Its politicisation, including the involvement and polarisation of actors, was on a par with the debate on the ratification of the Maastricht Treaty. In sum, economic governance is more politicised than other policies and its politicisation has increased over time.

Accordingly, Schimmelfenning (2014: 322) argues that the recent euro crisis contains the conditions for Hooghe and Marks (2009)'s postfunctionalism to offer better guidance. For these scholars, in an 
age of politicisation and public dissensus on European integration, outcomes may not reflect functional pressures any longer and identity-based contestation may make all the difference. If European issues are politicised on identity lines, we should see a 'downward pressure on the level and scope of integration' and a narrowing of the 'substantive ground of possible agreement' (Hooghe and Marks 2009: 21-2). For our purposes, this could be interpreted as loosening, less pooling and delegation, but Hooghe and Marks (2009: 21, 22) are more ambivalent. They tentatively conclude that politicisation may lead to both less integration (loosening) and more delegation - the latter presumably seen as a means to depoliticise an issue.

This indeterminacy is resolved in the recent wave of new intergovernmentalist theorizing that shares postfunctionalist premises such as the relevance assigned to the post-Maastricht rise in public dissensus and politicisation (Bickerton et al. 2015: 709-711; Fabbrini and Puetter 2016: 486). According to this variant, the post-Maastricht period is marked by 'integration without supranationalism' (Bickerton et al. 2015: 703). Initiatives are characterized by greater reliance on the European Council and the Council for policy execution and implementation (Fabbrini and Puetter 2016: 481). Delegation of powers 'to traditional supranational institutions such as the Commission [is] increasingly discredited among member state governments' (Puetter 2016: 604), de novo institutions are preferred, and unanimous decision-making within intergovernmental institutions acquires greater prominence (Fabbrini 2016: 593; Fabbrini and Puetter 2016: 488). This reluctance to pool and delegate is particularly relevant in highly salient or core state powers such as fiscal policy. These scholars do not seem to associate 'integration' with tighter national obligations, but rather with loose coordination measures that marginally encroach upon national policy autonomy. This is plausible in light of how politicisation operates. Once an issue becomes politicised, public dissensus restricts governments' room to manoeuvre, making them less inclined to relinquish sovereignty and even temped to reining in lost control (Hooghe and Marks 2009: 18-22; Puetter 2012: 168). Postfunctionalist scholars do not 
differentiate the impact of politicisation by country or government, but it could be argued for instance that politicisation may have led Germany to demand more delegation and tightening in the last reform, and Greece to push for the opposite. But this proposition is undistinguishable from liberal intergovernmentalist predictions as it is based on a government's expectation of being compliant, thus making politicisation epiphenomenal.

In conclusion, if the euro crisis has been an highly politicised identity conflict (Börzel and Risse 2018) or represents the 'apex of the [new] intergovernmental moment' (Fabbrini 2013: 1010), the functional pressures in policy design identified by liberal intergovernmentalism and neofunctionalism are disrupted and concerns about losing control are heightened. Therefore, economic governance should rely less on pooling and delegation and plausibly more on loosening, especially in politicised contexts. Table 1 summarizes the key expectations. Next, we explain our coding of policy design.

\section{Table 1: Expectations and driving mechanisms of policy design}

\begin{tabular}{lll}
\hline Integration theory & Expectations & Driving mechanisms \\
\hline Liberal & Pooling for additional measures, delegation for & Veto threats, exclusion threats and issue \\
intergovernmentalism & enforcement and implementation. Noncompliance & linkages shape outcomes \\
& leads to more delegation and plausibly tightening & \\
Neofunctionalism & Delegation also to benefit from centralized expertise & Exit costs, supranational institutions and \\
(institutionalist variant) & & decision-making also shape outcomes \\
Postfunctionalism / New & Less pooling and delegation, and plausibly loosening & Governments object to pooling and \\
intergovernmentalism & in salient policies and politicised contexts ${ }^{\dagger}$ & delegation and try to loosen obligations \\
\hline
\end{tabular}

Note: ${ }^{\dagger}$ Loosening and more delegation for Hooghe and Marks (2009). 


\section{Measuring the design of economic governance measures}

The EU economic governance regime is based on the chapter on economic policy and the protocol on the excessive deficit procedure (EDP) of the Treaty on European Union. Secondary measures include an EDP regulation, the stability and growth pact (SGP), made of a preventive, a corrective and a recent enforcement regulation. There are also ancillary acts harmonizing and monitoring national budgetary procedures. Additional measures, which we can only briefly discuss here, are the macroeconomic imbalance procedure (MIB) and the fiscal compact treaty (the Online Appendix lists provisions and the seventeen acts subject to our study).

We broadly follow the method of coding provisions developed in the American congressional literature and applied by Franchino (2007) to EU legislation. Each legal act, including treaty provisions and protocols, is subdivided into major provisions. Each major provision is coded if it imposes obligations on member states (tightening) or gives them leeway in implementing measures (loosening). Similarly, each major provision is coded if it pools policy authority within the Council (pooling), it delegates authority to the Commission (delegation) and it sets constraints upon these institutions. A provision can have multiple properties. For instance, it may delegate a policy prerogative, subject to constraints. We also determine whether pooled and delegated authority is related to an enforcement activity, such as establishing noncompliance or monitoring budgets. Provisions have been coded independently first, then disparities have been settled (coding rules are in the Online Appendix). Inter-coder agreement is 89 percent greater than would be expected by chance.

This procedure is reliable, easily replicable and produces data that greatly facilitate comparison across measures, time, and even policies, but it is not devoid of drawbacks. It treats policy prerogatives equally. A provision that confers upon the Commission the power to determine noncompliance has the same weight as one that asks this institution to adopt data collection guidelines. Also, a small change to an existing constraint, such as the shortening of a time limit, has to be either disregarded or double 
counted (we opted for the former). These shortcomings are not serious enough to distort the broad patterns we observe and, where necessary, we will compensate for this coarseness by distinguishing among types of policy prerogatives. On the other hand, we took two coding decisions to make sure that some important changes are detected. First, we code as constraint on the Council if this institution has to cooperate or co-decide with the Parliament, while disregarding simple consultation. Second, delegation is the granting of substantive policy authority to shape outcomes (Franchino 2007: 84). It excludes the sole examination of documents and the proposal prerogatives of the Commission, unless they are enhanced, that is, if less than a Council qualified majority is sufficient to adopt proposals. Here, the Commission has a significant chance of affecting outcomes.

Figure 1 displays the number of provisions in force after important reforms (see Online Appendix for detailed breakdowns). Major and tightening provisions have quintupled since the completion of the initial framework in 1997. Initially no provisions loosened control or conferred some policy leeway to member states, but since 2005 the number has moderately increased. Pooling provisions have remained constant until 2005, and then they almost tripled. The associated constraints tripled both with the initial SGP and with the latest reforms. Instead, apart from standard proposal prerogatives, no provisions delegated powers to the Commission until the 2005 reform of the EDP. The total tally is now almost ten times larger and the associated constraints have sextupled since.

The following analysis of negotiations is also based on information on contested issues and positions of institutional and governmental actors. The methodology for collecting these data, including a detailed account of the sources and strategies of identification and cross-validation, is available in the Online Appendix. 
Figure 1: Major and design economic governance provisions in force
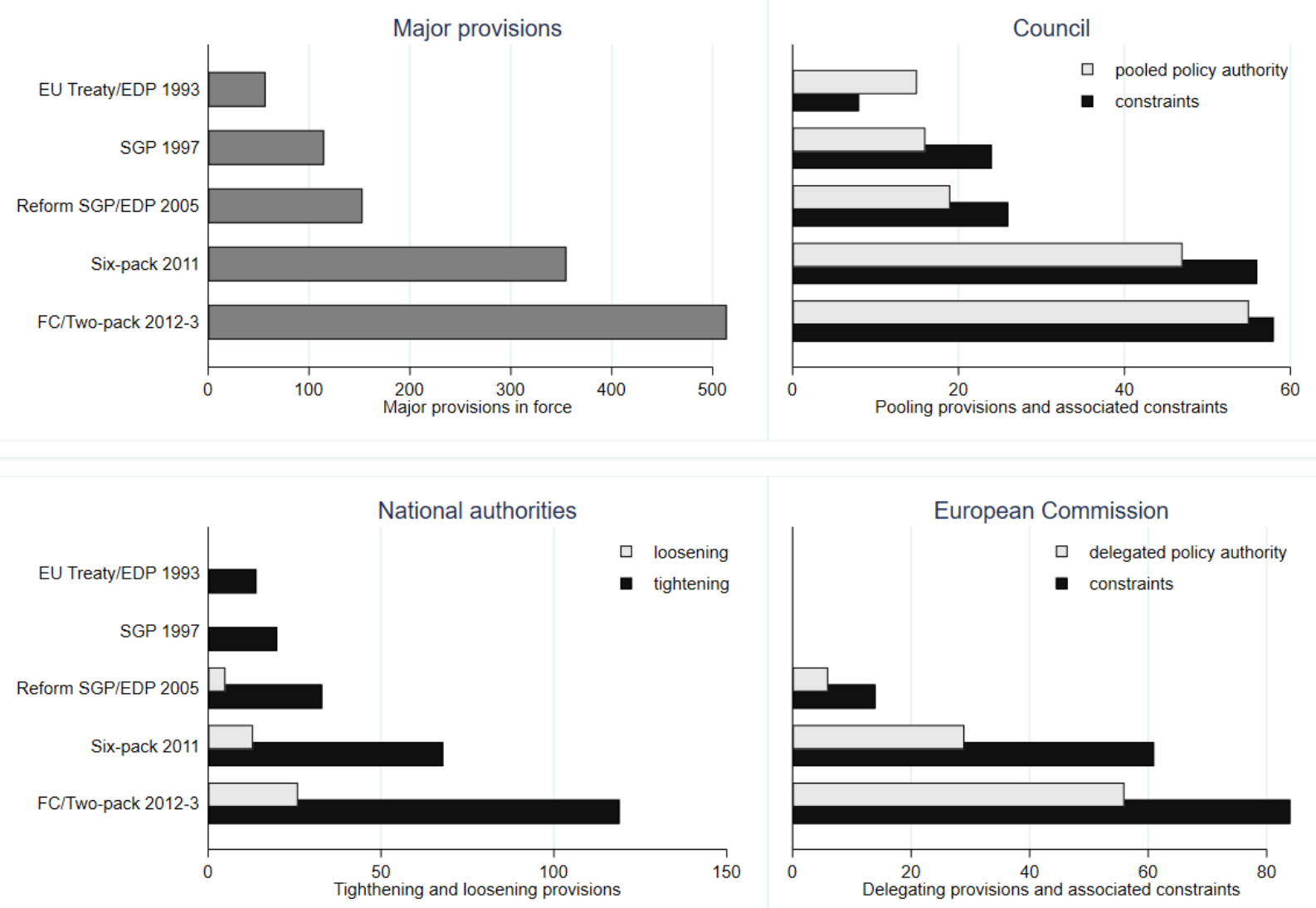

Note:Cumulative figures. EDP:Excessive Deficit Procedure, SGP:Stability and Growth Pact, FC:Fiscal Compact

\section{The initial design: Why so much pooling?}

\section{Council-centred enforcement}

Figure 2 displays the regime after major reforms in terms of shares of design provisions, while Figure 3 displays the share of pooling and delegating provisions that are related to an enforcement activity. Only pooling occurred by the time the initial framework was completed in 1997. Apart from proposal competences, no provisions delegated powers to the Commission or granted some leeway to member states. Council constraining provisions and tightening provisions were similarly employed.

The Maastricht treaty (and the proximate EDP regulation) set some general demands on member states on coordination and reporting of economic policies and public finances, and more specific 
requirements, such as the well-known obligation to avoid excessive government spending, with the associated reference values of deficit and debt to GDP. We will not discuss here treaty negotiations, but the initial design is not fully aligned with liberal intergovernmentalism. As expected, prerogatives were pooled where rules on financing, bailout, multilateral surveillance and the EDP had to be laid down, but pooling occurred also with regard to the publicity of recommendations establishing inconsistency between national measures and broad economic guidelines, and the determination and sanctioning of excessive deficits. Two thirds of pooling provisions concerned enforcement (see Figure 3). The absence of delegation betrays a lack of concern about compliance and it is a likely indication of the unique salience of the policy, as postfunctionalist scholars emphasize.

Figure 2: Economic governance by proportion of design provisions in force

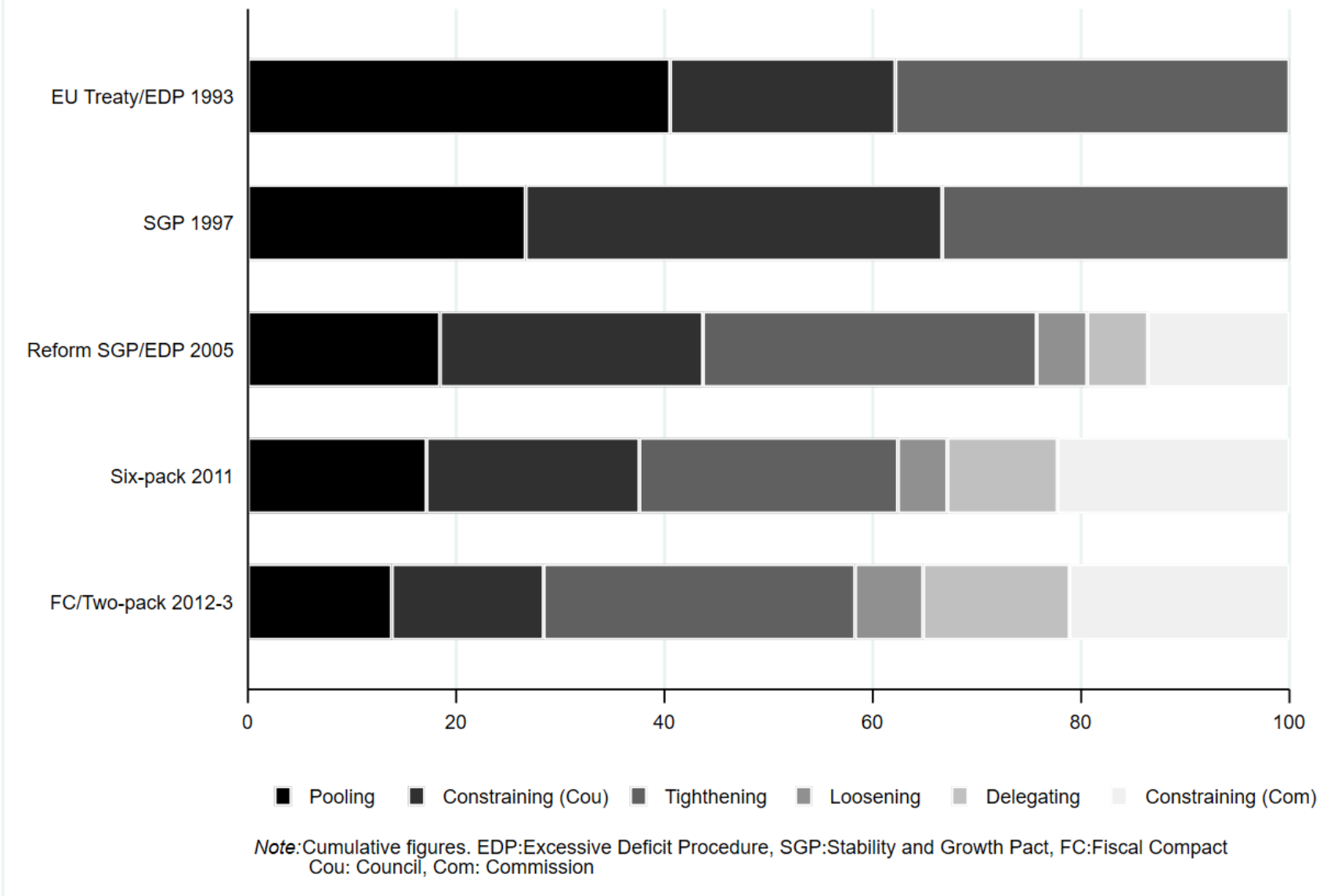




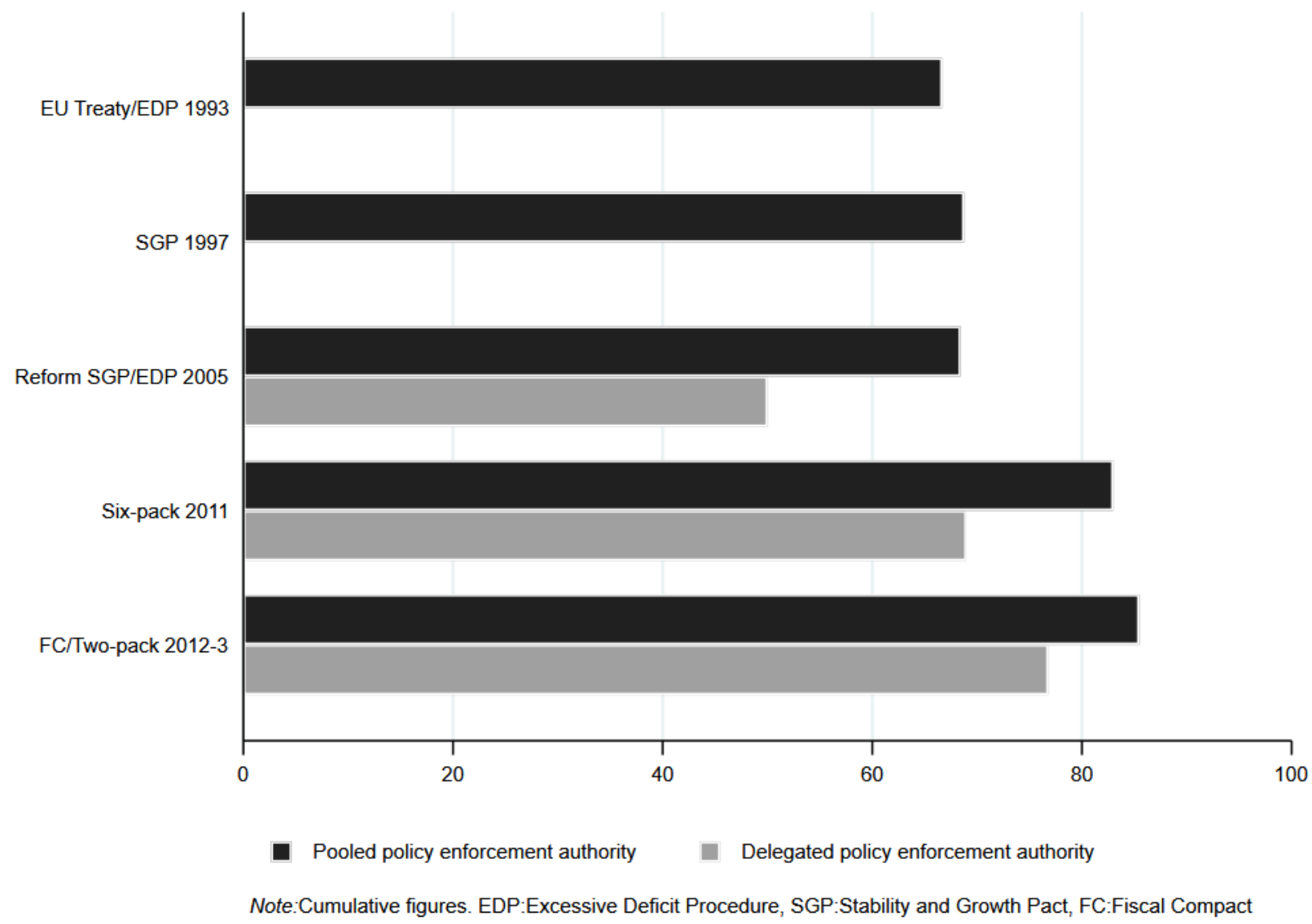

\section{Noncompliance, threat of exclusion and contested issues}

Noncompliance as well did not have all the consequences expected by liberal intergovernmentalism. Figure 4 illustrates the periods under which governments have not been compliant with key provisions of the regime (we employ a looser benchmark for debt). Consider only the deficit criteria for the time being. By 1996, the Council established that every member state had an excessive deficit, except for Ireland and Luxembourg. As the deadline for selecting countries that would have adopted the euro was approaching and as it became clear that those with a history of fiscal profligacy, like Italy, may have been in the first wave, the German government pressed for a strengthening of the regime, under an implicit but credible threat of a smaller Eurozone. 
Yet, delegation was barely an issue. Negotiations centred on the circumstances under which a deficit would not be considered excessive, the automaticity of the procedure and the size of the sanctions. The first two issues were about the Council's room of manoeuvre. The German and Dutch governments argued for specific thresholds (Agence Europe 1996: 5) and proposed that automatic exemptions should apply only to countries experiencing an annual decline in real GDP of at least 2 percent. The Belgian, French and Italian governments preferred keeping the Council free to determine countryspecific exceptional circumstances. The 2 percent threshold was eventually included in article 2.2 of the SGP corrective arm, but the third comma stipulated that circumstances could be exceptional also for a contraction of less than 2 percent, 'in light of further evidence'. It was a modest amendment. A resolution of the Amsterdam European Council summit of June 1997 further narrowed the Council's faculty to exempt noncompliant countries to cases when the reduction was more than 0.75 percent, so called 'box model'. In sum, the most recalcitrant countries accepted to limit Council's powers only in case of mild recessions and this exception was not even included as a legal provision in the SGP.

In the second contested issue, the German, Danish, Finnish and Swedish governments proposed to insert the words 'the expectation is that the Council will respect the Commission's decision'. They settled for the inclusion of the words 'as a rule' in articles 2 and 11 . The last contested topic concerned the deposit to be made in case of an excessive deficit. The German government argued for a fixed component of 0.25 percent of GDP, but it had to settle with the Commission proposal of 0.2 percent, which was supported by the majority of governments. 
Figure 4: Periods of noncompliance with fiscal provisions
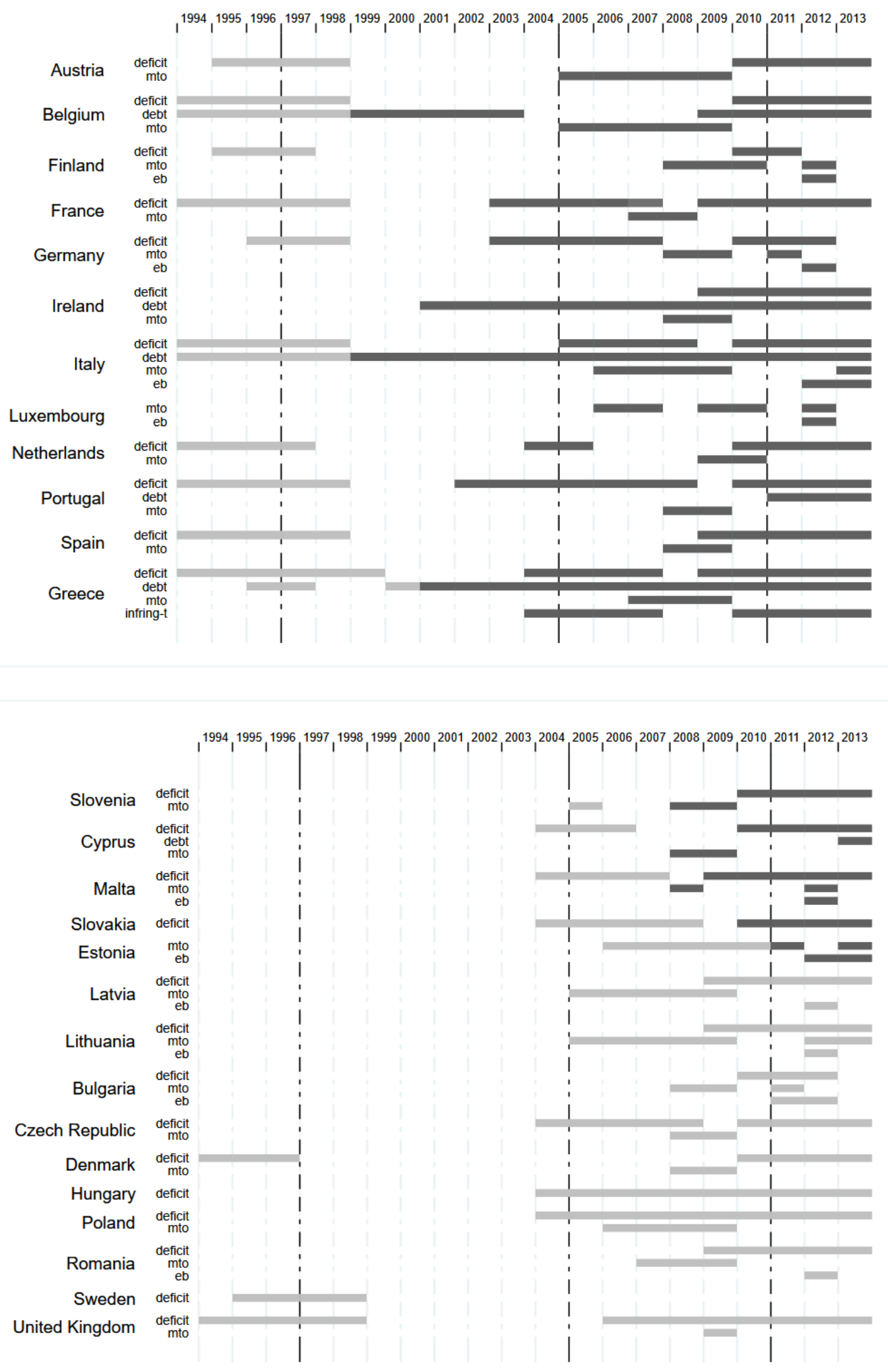
Note: Excessive deficit, debt greater than GDP, medium-term objective (mto), expenditure benchmark (eb), infringements. Darker bars for years with euro. Vertical lines separate reforms. See Online Appendix for more details.

\section{Explaining pooling in the SGP: Veto power and policy uncertainty}

Some demands for tightening were met in the SGP. The preventive measure required states to submit annual stability or convergence programmes, with an MTO of close to balance or in surplus. The need to assembly only a qualified majority in the Council for its adoption may have facilitated this outcome, as neofunctionalism suggests. On the other hand, the corrective regulation primarily circumscribed Council prerogatives by establishing conditions for an excessive deficit, deadlines and sanctions (see Figures 1 and 2). The bargaining dynamics emphasized by liberal intergovernmentalism is in clear display here. While the most recalcitrant governments caved in and agreed to revise the regime in order to defuse the threat of exclusion, these governments were empowered by the unanimity requirement. Keen to preserve Council's prerogatives, they made modest concessions to the most reformist colleagues, in order to signal commitment to fiscal stability, but avoided delegation. However, the SGP remained overall a modest reform in terms of policy design, with pooling still dominant in enforcement despite noncompliance. Two thirds of pooled prerogatives were related to this activity (see Figure 3).

From a postfunctionalist perspective, limited tightening and no delegation is the result of the unique salience of the policy. But one ingredient is missing. There is hardly evidence that the conflict surrounding these negotiations turned into mass public debates, despite raising politicisation in the 1990s (Hutter et al. 2016). In our view, other important factors militating against delegation were the uncertainties surrounding these rules. This regime's primary objectives are to prevent moral hazard in public spending in a monetary union and to limit negative externalities associated with the possible 
combination of expansionary fiscal policies and a contractionary monetary policy (the former resulting from governments' attempts to use fiscal policy to boost output and employment in the short-term at the expense of inflation, the latter from an inflation-averse common central bank). These rules should ensure sustainable public debts, allowing enough flexibility for countercyclical policies (e.g. Claeys $e t$ al. 2016).

At the time of drafting the SGP however, these externalities were purely hypothetical consequences of establishing a monetary union. Some scholars downplayed their magnitude and questioned their direction. Buiter et al. (1993) explicitly argued for the reference values to be disregarded. No bailout rules were deemed sufficient to deal with the risk of default and with financial contagion: governments would avoid excessive spending anyway, if the central bank is credibly inflation-averse and if financial markets demand higher risk premia from profligate governments (see also Buiter 2006; Eichengreen and Wyplosz 1998). However, the commitments to no bailout and to stable prices were obviously untested, while the prospects of countries with histories of fiscal improvidence joining the monetary union were becoming concrete.

Another concern was that these reference values could induce pernicious pro-cyclical policies since governments may have to cut spending or raise taxes during a recession (thus, undermining the credibility of financial sanctions), while they could increase spending or cut taxes during a recovery. Efficacy aside, several different combinations of debt and deficit values are fiscally sustainable, so any given set of parameters is necessarily arbitrary and it risks being excessively constraining (Pasinetti 1998). 


\section{The 2005 reform: Why loosening despite noncompliance?}

\section{Loosening and modest delegation}

This reform introduces two small but significant changes. First, four provisions (6 percent of design provisions in force) grant member states greater flexibility. Most were inserted in the preventive SGP regulation. Article 2 a replaces a common MTO (recall, the structural budget objective) with a revisable country-specific one, which may now diverge by no more than 1 percent of GDP from a balance or surplus position. On the other hand, the EDP regulation adds new obligations about the provision of statistical data, professionalism of statistics officials and assistance to Commission's inspections. Hence, about a third of the policy design still consists of tightening provisions.

The second significant change concerns six provisions in the EDP regulation conferring policy prerogatives upon the Commission (amounting to 6 percent of design provisions). The Commission sets statistical formats, adopts data collection guidelines, and determines the implementation of accounting rules. Importantly, the supranational executive can object to the quality of reported data and amend them.

The role of the Council is unaltered, on balance. On the one hand, the definition of severe economic downturn - a key contested issue in 1997 - is relaxed. The box model is dropped, and now even a protracted period of very low growth can be a mitigating factor to avoid the procedure. Decisions can be revised in case of unexpected adverse events and the assessment time frame is extended. ${ }^{1}$ On the other hand, the preventive regulation clarifies the criteria for examining structural budgets in light of the MTOs; while the corrective regulation specifies that the Council must request minimum annual

\footnotetext{
${ }^{1}$ Except perhaps for pension reforms, it is unclear whether the criteria for evaluating budgets listed in the corrective regulation allows for greater discretion.
} 
improvements of the structural budget of 0.5 percent of GDP from noncomplying states. Deadline extensions cannot exceed one year.

\section{Consequences of EDP regulation noncompliance: Tightening and delegation}

As Figure 4 illustrates, after a respite of a few years, noncompliance reappeared. In 2004, Eurostat revised upwards the Greek deficit by between 2 and 3 percentage points of GDP for the years 2000 to 2003 and the 2003 debt-GDP ratio by more than 7 percentage points. In December 2004, the Commission initiated an infringement procedure against Greece for failing to comply with the EDP regulation. The new design corroborates liberal intergovernmentalism. National obligations were tightened and Commission's competences expanded. Half of delegating provisions relates to enforcement, the remaining half to implementation (see Figure 3). Qualified majority may have helped addressing these demands, as neofunctionalism suggests. The most contentious issue indeed concerned Commission's prerogatives. The four largest countries opposed regular methodological inspections of national data as well as a first in-depth monitoring visit, proposed by Luxembourgish Presidency. Article 8d narrowly defines the objectives of these visits and specifies that they should take place only in case of serious problems.

This reform runs counter postfunctionalist expectations but some of their scope conditions were absent. Conflict remained circumscribed to the elite level in these negotiations. Recent works actually indicate that debates on European issues in the early 2000s were less politicised than in the previous decade (Hutter et al. 2016: 281). 


\section{Consequences of SGP noncompliance: Loosening, reversion point and policy uncertainty}

Governments also failed to comply with the fiscal rules. Between 2000 and 2004, four Eurozone countries, including France and Germany, had an excessive deficit, while high indebtedness persisted in some other countries. Yet, in shifting the focus from correction to prevention, the SGP loosened some national obligations and relaxed some Council constraints, while the Commission obtained no new substantive powers. Moreover, the corrective regulation pools two additional enforcement-related prerogatives concerning the revision of decisions.

This outcome is not easy to reconcile with postfunctionalism, given limited politicisation, nor with liberal intergovernmentalism, given noncompliance. A qualified majority might have been easier to assemble in the preventive arm. Indeed, the 1 percent floor to the divergence from the MTO was inserted by the Council. But this reform of the corrective arm, which requires unanimity, is unexpected at first sight. By far the most controversial issue concerned the numerousness and specificity of mitigating factors for establishing an excessive deficit. The conflict replicated the 1997 divide, but with the German position reversed. This time chancellor Gerhard Schröder argued for more leniency and proposed a long list of factors that was viewed favourably by France and Italy. These governments either were noncompliant or risked being so. In March 2005, Luxembourgish Jean-Claude Juncker, presiding the Council, proposed a shorter list, which was criticized by both governments that wanted to add specific spending categories (the three above plus the United Kingdom) and those that considered it too long and insisted on the centrality of the reference values. The more recalcitrant Eurozone countries had a history of better compliance (except for the Netherlands). This list was eventually abandoned in favour of a somewhat fuzzy but still long enumeration of factors in article 2.3 and an invitation to a "balanced overall assessment". As an "overarching principle", mitigation would be considered only if the deficit remained close to the reference value and its excess was temporary. 
Nevertheless, considering also the laxer criteria of protracted low growth as mitigating factor, these changes undeniably expanded Council discretion and diluted control over national authorities.

Why did recalcitrant and mostly compliant governments not veto these developments and push for delegation? Liberal intergovernmentalism proves its usefulness by directing our attention to the no agreement outcome. The reversion point of these negotiations was the suspension of the EDP - clearly an unpleasant outcome for these fiscally responsible governments. In November 2003 France and Germany managed to assemble a minority to block decisions establishing the insufficiency of their measures and demanding further action under the threat of sanctions (Heipertz and Verdun 2010: 142154). The Council also declared that the procedure was held in abeyance. Although this latter decision was successfully challenged by the Commission before the European Court of Justice in July 2004, the Court upheld the Council's right to block decisions. It was therefore clear that there was a minority blocking any new Commission's recommendation - a de facto abeyance. The least reformist countries had therefore to accept a looser regime and more emphasis on preventive surveillance in exchange of resuming the procedure and stricter constraints once an excess was determined. The unpalatable consequences of no agreement defused the threats of veto and engendered willingness to compromise.

Given several governments pushing for loosening and more Council leeway, we should hardly expect delegation. This is in line with postfunctionalism, were it not for the limited politicisation. But in our view, the prevailing reluctance to delegate may have also been motivated by the renewed emphasis on the structural budget: an unobservable quantity subject to significant estimation errors, ${ }^{2}$ which depends on estimates of the output gap - also an unobservable quantity that in turn depends on estimates of, for instance, total factor productivity and (non-accelerating wage) rate of unemployment. Forecasting

\footnotetext{
${ }^{2}$ Yearly revisions of the structural balance are larger than 0.5 percent of GDP, i.e. the required baseline annual adjustment (Claeys et al. 2016: 6).
} 
errors of output growth and inflation add further uncertainty. In sum, governments agreed to a preventive surveillance based on an imprecise indicator over which they had limited control. No wonder they were not inclined to delegate.

\section{The euro crisis: Policy failure and enforcement reform}

\section{Delegation and tightening}

This overhaul of economic governance was adopted in the midst of the sovereign debt crisis. In Figures 1 and 2, we distinguish between the six-pack on the one side, and the two-pack and fiscal compact on the other. These measures are part of the same reform, even though they span over a three-year period. As Figure 1 shows, the number of major provisions more than tripled and the main beneficiary is undoubtedly the Commission. Figure 2 reports that the share of delegating provisions has moved from 6 to 14 percent and the share of pooling provisions are correspondingly decreased from 18 to 14 percent. Provisions giving national authorities some leeway, mostly exemptions, have marginally increased from 5 to 7 percent. With more powers, provisions constraining the Commission have correspondently increased from 14 to 21 percent, while the Council share has decreased from 25 to 15 percent. The proportion of tightening provisions has barely altered. Almost half of new ones are included in the two-pack, less than a quarter in the budgetary frameworks directive and a tenth in the fiscal compact.

The reform establishes more precise assessment benchmarks: an annual real expenditure growth to assess progress toward the MTO in the preventive regulation and an annual rate of improvement of the debt-GDP ratio for countries exceeding the reference value in the corrective regulation. The fiscal compact narrows to 0.5 percent of GDP the acceptable MTO divergence for countries exceeding the debt reference value. 
The strengthening of Commission's power is both procedural and substantive and occurs primarily in four measures (adopted with the ordinary legislative procedure): the SGP preventive regulation, the new SGP enforcement regulation and the two-pack regulations (the Online Appendix summarizes noteworthy delegating provisions). Notably, 77 percent of them are enforcement related (see Figure 3).

On the other side, accountability to the Parliament has been strengthened through its involvement in the economic dialogue and its oversight of Commission delegated acts.

Although the shift in policy design from pooling to delegation is clear, the triplicated pooling provisions are still predominantly enforcement related (85 percent, see Figure 3). In the SGP enforcement regulation, sanctioning remains centred on the Council. In the two-pack surveillance regulation, this institution approves adjustment programmes, establishes noncompliance and sets conditionality requirements. A third of the new pooling provisions comes from the MIB, and the enforcement of this measure relies more on the Council than on the Commission, compared to the SGP.

\section{Explaining the overhaul: Noncompliance, exit cost and issue linkage}

As Figure 4 illustrates, the patterns of noncompliance leading up to this reform amounted to a policy failure. The significant revisions of the Greek government deficit in late 2009 raised serious concerns about data quality and led to opening an infringement procedure. This was the proximate cause of the sovereign debt crisis but the preceding financial crisis had already put public finances under serious strain. The structural balance of every single Eurozone country, except Slovakia, intermittently diverged from the MTOs. Public indebtedness worsened. Then, in 2010, every country, except for Luxemburg, ran an excessive deficit, while Greece, Ireland and Portugal had to secure bailout loans. Negotiations were also highly mass politicised (Genschel and Jachtenfuchs 2018; Kriesi and Grande 2016), making this reform a sort of critical test of these theories. 
Overall, liberal intergovernmentalism and neofunctionalism are more convincingly corroborated. As Schimmelfennig (2015: 184) aptly puts it, the ensuing bargaining dynamics took the form of a game of chicken between fiscally sound governments and those under pressure for financing their outlays. The significant risks of dissolution of the Eurozone - an exit option of vast consequences - compelled them to solve the crisis but each preferred to shift the burden of adaptation on the counterpart. The former sought commitment to fiscal discipline, the latter to bailout. ${ }^{3}$ For instance, this linkage explains why the Italian and Greek governments, despite their power to veto the corrective regulation, accepted the new benchmark of a debt-GDP ratio improvement for highly indebted countries (but successfully opposed demands to narrow the mitigating factors for determining an excessive deficit).

In the other measures, the shift in policy design toward tightening and delegation (especially for noncompliance and sanctioning decisions, with the consequence of narrowing Council influence) has also been facilitated by Council qualified majority voting (and parliamentary involvement). For instance, in the preventive regulation, the discussion centred on a) a different MTO adjustment path for highly indebted countries and b) the consequences of budgetary deviations. The Italian government argued against a differentiated assessment and, together with the Greek government, against sanctions for deviations. The new article 5.1 instead demands the Council and the Commission to examine whether annual budgetary improvements reach at least 0.5 percent of GDP for these countries (the Finnish, Dutch and Luxembourgish governments pressed for a more explicit requirement, which was eventually inserted in the fiscal compact). Moreover, article 5.1 not only operationalizes the adjustment

\footnotetext{
${ }^{3}$ For positions on capacity building measures, see Lehner and Wasserfallen (2019). As corroborating evidence, we find Germany, Finland and the Netherlands opposing article 13.4 of the SGP enforcement regulation that demands the Commission to draft a report on Eurobonds.
} 
path through an expenditure benchmark, but the new article 6.2 also demands the Council to act within a month of a warning; and sanctions are envisioned.

Politicisation did not engender a convergence of positions over policy design. Benelux governments even proposed to extend the enhanced proposal prerogatives of the Commission to more SGP and MIB provisions. The Parliament was instead instrumental for including sanctions for manipulating statistics in the SGP enforcement regulation and for keeping Council qualified majority voting for approving adjustment programmes in the two-pack, over the opposition of several ministers.

In sum, noncompliance and the pressure of securing commitment to both fiscal soundness and bailout produced a reform in the direction predicted by liberal intergovernmentalism. Additionally, as neofunctionalism expects, prohibitive exit costs limited available options and lower procedural hurdles facilitated tightening and delegation. These changes are not unexpected (cf. Bauer and Becker 2014; Dehousse 2016). Delegation may have been also perceived as less risky since the Commission has been building up non-trivial policy capabilities over time (Savage and Verdun 2016). And, although uncertainties persist, the new expenditure rule is a step toward more certain and controllable performance indicators (Claeys et al. 2016).

\section{Conclusion}

We cannot rely on a single theory to understand economic governance design. Contrary to liberal intergovernmentalist expectations, enforcement has been heavily Council-centred until 2011, despite significant noncompliance, as it is in the recent two-pack surveillance regulation and MIB. As postfunctionalist theories suggest (pooling aside), the salience of this policy has quite likely underlain the reluctance to tighten and delegate. But these approaches fall short in highly politicised contexts, exactly where they should do most of the explaining. In our view, the unavoidable arbitrariness and 
uncertainties of these rules must also have cautioned against relying on a supranational executive with limited resources.

Liberal intergovernmentalism and neofunctionalism remain valuable for explaining the overall direction of these reforms toward tightening, restricting Council authority and delegation - precipitated by noncompliance and characterized by commitment problems, threats of exclusion and veto, issue linkages, path dependencies and more supranational decision-making. Attention to these bargaining dynamics helps illuminating outcomes, even when loosening follows noncompliance, while functional logics, such as the need to secure credible commitments, appear unaltered.

In conclusion, policy-makers do not seem to react to mass politicisation by loosening obligations and avoiding pooling and delegation. They do not cave in and ensure that the policy remains or returns under national control. The 'new intergovernmental moment' saw a move from Council- to Commission-centred enforcement, without relying on new institutions. Tightening, pooling and delegation occurred despite the highly politicised negotiations of the recent reform. Response-wise, these changes indicate that, in the face of rising domestic public pressures, EU-level actors have adopted a strategy of assertive depoliticisation, although without shying away from open confrontation (Bressanelli et al. forthcoming). Facing the serious consequences of a Eurozone break-up, this is indeed the type of reactive politicisation management ministers (and parliamentarians) would be expected to undertake, despite their electoral accountability and the domestic salience of this core state policy (Schimmelfennig forthcoming). Nor should we ignore the plausible assertion that mass domestic politicisation in the latest reform was triggered by noncompliance and elite conflict, which may also explain why leaders have decided to assertively pursue (institutional) depoliticisation.

\section{References}

Agence Europe (1996) Europe Daily Bullettin n. 6851, 12 November: 5. 
Bauer, M. W. and Becker, S. (2014) 'The Unexpected Winner of the Crisis: The European Commission's Strengthened Role in Economic Governance', Journal of European Integration 36(3): 213-229.

Bickerton, C. J., Hodson, D. and Puetter, U. (2015) 'The New Intergovernmentalism: European Integration in the Post-Maastricht Era', Journal of Common Market Studies 53(4): 703-722.

Biermann, F., Guérin, N., Jagdhuber, S., Rittberger, B. and Weiss, M. (2019) 'Political (non-)reform in the euro crisis and the refugee crisis: a liberal intergovernmentalist explanation', Journal of European Public Policy 26(2): 246-266.

Börzel, T. A. and Risse, T. (2018) 'From the euro to the Schengen crises: European integration theories, politicization, and identity politics', Journal of European Public Policy 25(1): 83-108.

Bressanelli, E., Koop, C. and Reh, C. (forthcoming) 'EU Actors under Pressure: Politicisation and Depoliticisation as Strategic Responses', Journal of European Public Policy.

Buiter, W. H. (2006) 'The "Sense and Nonsense of Maastricht" Revisited: What Have we Learnt about Stabilization in EMU?', Journal of Common Market Studies 44(4): 687-710.

Buiter, W. H., Corsetti, G., Roubini, N., Repullo, R. and Frankel, J. (1993) 'Excessive Deficits: Sense and Nonsense in the Treaty of Maastricht', Economic Policy 8(16): 57.

Claeys, G., Darvas, Z. and Leandro, À. (2016) A Proposal to Revive the European Fiscal Framework, Brussels: Bruegel.

Dehousse, R. (2016) 'Why has EU macroeconomic governance become more supranational?', Journal of European Integration 38(5): 617-631. 
Eichengreen, B. and Wyplosz, C. (1998) ‘The Stability Pact: More than a Minor Nuisance?', Economic Policy 13(26): 65-113.

Fabbrini, S. (2013) 'Intergovernmentalism and Its Limits Assessing the European Union's Answer to the Euro Crisis', Comparative Political Studies 46(9): 1003-1029.

Fabbrini, S. (2016) 'From consensus to domination: the intergovernmental union in a crisis situation', Journal of European Integration 38(5): 587-599.

Fabbrini, S. and Puetter, U. (2016) 'Integration without supranationalisation: studying the lead roles of the European Council and the Council in post-Lisbon EU politics', Journal of European Integration 38(5): 481-495.

Franchino, F. (2007) The Powers of the Union: Delegation in the EU, Cambridge: Cambridge University Press.

Garrett, G. and Tsebelis, G. (1996) 'An Institutional Critique of Intergovernmentalism', International Organization 50(2): 269-299.

Genschel, P. and Jachtenfuchs, M. (2018) 'From Market Integration to Core State Powers: The Eurozone Crisis, the Refugee Crisis and Integration Theory', Journal of Common Market Studies 56(1): 178-196.

Heipertz, M. and Verdun, A. (2005) 'The Stability and Growth Pact - Theorizing a Case in European Integration', Journal of Common Market Studies 43(5): 985-1008.

Heipertz, M. and Verdun, A. C. (2010) Ruling Europe: the politics of the stability and growth pact, Cambridge: Cambridge University Press. 
Hooghe, L. and Marks, G. (2009) 'A Postfunctionalist Theory of European Integration: From Permissive Consensus to Constraining Dissensus', British Journal of Political Science 39(1): 123.

Hutter, S., Grande, E. and Kriesi, H. (2016) Politicising Europe: Integration and Mass Politics, Cambridge University Press.

Kriesi, H. and Grande, E. (2016) 'The Euro Crisis: A Boost to the Politicisation of European Integration?', in S. Hutter, E. Grande, and H. Kriesi (eds). Politicising Europe: Integration and Mass Politics. Cambridge: Cambridge University Press, pp. 240-276.

Lehner, T. and Wasserfallen, F. (2019) 'Political conflict in the reform of the Eurozone', European Union Politics 20(1): 45-64.

Moravcsik, A. (1998) The Choice for Europe: Social Purpose and State Power from Messina to Maastricht, Ithaca: Cornell University Press.

Niemann, A. and Ioannou, D. (2015) 'European economic integration in times of crisis: a case of neofunctionalism?', Journal of European Public Policy 22(2): 196-218.

Pasinetti, L. L. (1998) 'The myth (or folly) of the 3\% deficit/GDP Maastricht "parameter", Cambridge Journal of Economics 22(1): 103-116.

Pierson, P. (1996) 'The Path to European Integration. An Historical Institutionalist Analysis', Comparative Political Studies 29(2, April): 123-163.

Puetter, U. (2012) 'Europe's deliberative intergovernmentalism: the role of the Council and European Council in EU economic governance', Journal of European Public Policy 19(2): 161-178. 
Puetter, U. (2016) 'The centrality of consensus and deliberation in contemporary EU politics and the new intergovernmentalism', Journal of European Integration 38(5): 601-615.

Savage, J. D. and Verdun, A. (2016) 'Strengthening the European Commission's budgetary and economic surveillance capacity since Greece and the euro area crisis: a study of five Directorates-General', Journal of European Public Policy 23(1): 101-118.

Schimmelfennig, F. (forthcoming) 'Politicization management in the European Union', Journal of European Public Policy.

Schimmelfennig, F. (2014) 'European Integration in the Euro Crisis: The Limits of Postfunctionalism', Journal of European Integration 36(3): 321-337.

Schimmelfennig, F. (2015) 'Liberal intergovernmentalism and the euro area crisis', Journal of European Public Policy 22(2): 177-195.

Schure, P. and Verdun, A. (2008) 'Legislative Bargaining in the European Union: The Divide between Large and Small Member States', European Union Politics 9(4): 459-486.

Segers, M. and van Esch, F. (2007) 'Behind the Veil of Budgetary Discipline: The Political Logic of the Budgetary Rules in EMU and the SGP', Journal of Common Market Studies 45(5): 10891109.

Verdun, A. (2015) 'A historical institutionalist explanation of the EU's responses to the euro area financial crisis', Journal of European Public Policy 22(2): 219-237. 